九州大学学術情報リポジトリ

Kyushu University Institutional Repository

\title{
Synthesis and Plant Growth Regulatory Activity of 1, 5-Disubstituted Imidazoles
}

Kikuchi, Masamichi

Laboratory of Pesticide Chemistry, Faculty of Agriculture, Kyushu University

Kuwano, Ei ichi

Laboratory of Pesticide Chemistry, Faculty of Agriculture, Kyushu University

Eto, Morifusa

Laboratory of Pesticide Chemistry, Faculty of Agriculture, Kyushu University

https://doi.org/10.5109/23906

出版情報 : 九州大学大学院農学研究院紀要. 34 (4)，pp. 397-404，1990-03. Kyushu University バージョン：

権利関係 : 


\title{
Synthesis and Plant Growth Regulatory Activity of 1, 5-Disubstituted Imidazoles
}

\author{
M asamichi K ikuchi, E iichi $K$ uwano and M orifusa E to \\ Laboratory of Pesticide Chemistry, Faculty of Agriculture, \\ Kyushu University 46-02, Fukuoka 812, Japan \\ (Received October 19, 1989)
}

\begin{abstract}
A large number of 1, 5-disubstituted imidazoles were synthesized and bioassayed for plant regulatory activity on the lettuce seedlings. Most of the compounds inhibited the growth of hypocotyls and weakly stimulated the growth of roots at $10 \mathrm{ppm}$. Of the compounds tested, 5-(2-hydroxyphenyl)-1-neopentylimidazole (15), 5-(2-methoxyphenyl)-1-neopentylimidazole (22), 5-(2-ethoxyphenyl)-1-neopentylimidazole (23) and 5-(3-chlorophenyl)-1-neopentylimidazole (26) showed high inhibitory activity in the growth of hypocotyls. The growth-retardant activity of the above compounds was annulled fully by application of gibberellic acid (GA,).
\end{abstract}

\section{INTRODUCTION}

Several 1-substituted 1, 2, 4-triazoles such as paclobutrazol 〔1-(4-chlorophenyl)4, 4-dimethyl-2-(1H-1, 2, 4-triazol-1-yl) pentan-3-ol 〕, triapenthenol〔(E)-1-cyclohexyl-4,4-dimethyl-2-(1\&1, 2, 4-triazol-1-yl)-1-penten-3-ol] and uniconazole $[(E)$ 1-(4-chlorophenyl)-4, 4-dimethyl-2-(1 H-1, 2, 4-triazol-l-yl)-1-penten-3-ol) have sofar been developed as plant growth regulators (PGRs). The main effect of these triazoles on plants is an inhibition of shoot growth. It has been found that the precise target site of these PGRs is the oxidation step of ent-kaurene to ent-kaurenoic acid in the gibberellin biosynthesis pathway, which is catalyzed by a cytochrome P-450 system (Köller, 1987). It has been also reported that a number of 5-substituted pyrimidines (Sisler et al., 1984), 4-substituted pyridines and 1-substituted imidazoles (Rademacher et al., 1987) inhibit the gibberellin biosynthesis and show plant growth regulatory activity resulting in growth retardation.

We have been interested in 1, 5-disubstituted imidazoles as a potent inhibitor of a cytochrome P-450 and have reported on the insect growth regulatory activity of 1, 5disubstituted imidazoles (Kuwano et al., 1985). However, there is no report on the plant growth regulatory activity of 1, 5-disubstituted imidazoles. We therefore prepared a new series of 1,5-disubstituted imidazoles in order to elucidate the activity on plants.

\section{EXPERIMENTAL}

\section{Synthesis}

All melting points were uncorrected. ${ }^{1} \mathrm{H}$ NMR spectra were determined on a JEOL JNM-FX 100 spectrometer using $\mathrm{Me}_{4} \mathrm{Si}$ as an internal standard, and all samples were prepared in $\mathrm{CDCl}_{3}$. 
$\mathrm{N}$-(a-tosylalkeny1)formamide.s (1) and 1-isocyano-1-tosyl-1-alkenes (2) were prepared according to the method described by van Leusen et al. (1977, 1979).

1-Methoxycarbonylmethyl-5-phenylimidazole (4)

To a solution of 1-isocyano-2-phenyl-1-tosylethene $\left(2, \mathrm{R}^{5}=\right.$ phenyl, $6.6 \mathrm{~g}, 20.0$ $\mathrm{mmol})$ in $60 \mathrm{ml}$ of methanol was added a solution of glycine methyl ester hydrochloride $(6.4 \mathrm{~g}, 21.0 \mathrm{mmol})$ and triethylamine $(6.6 \mathrm{~g}, 47.4 \mathrm{mmol})$ in $30 \mathrm{ml}$ of methanol. After stirring for 7 days at room temperature, to the mixture was added water and the product was extracted with dichloromethane. The dichloromethane solution was washed with brine, dried over $\mathrm{Na}_{2} \mathrm{SO}_{4}$, and concentrated. The residue was chromatographed on silica gel and eluted with $3 \%$ isopropyl alcohol in ethyl acetate. The eluate was concentrated to give $2.27 \mathrm{~g}(53 \%)$ of 4 . NMR $\delta: 3.72(3 \mathrm{H}, \mathrm{s}), 4.66(2 \mathrm{H}, \mathrm{s}), 7.07(1 \mathrm{H}$, $\mathrm{d}, \mathrm{J}=1 \mathrm{~Hz}), 7.2-7.5(5 \mathrm{H}, \mathrm{m}), 7.55(1 \mathrm{H}, \mathrm{d}, \mathrm{J}=1 \mathrm{~Hz})$.

1-(3,3-Dimethyl-2-oxobutyl)-5-phenylimidazole (5)

A solution of t-butyllithium in hexane $(1.48 \mathrm{M}, 10 \mathrm{ml}, 15 \mathrm{mmol})$ was added dropwise at a temperature between -70 and $-60^{\circ} \mathrm{C}$ to a solution of $4(2.09 \mathrm{~g}, 9.68$ $\mathrm{mmol}$ ) in $50 \mathrm{ml}$ of dry ether. After stirring for $2 \mathrm{hr}$ at $-70^{\circ} \mathrm{C}$ and for $3 \mathrm{hr}$ at room temperature, the mixture was poured into $1 \%$ ammonium chloride solution. The product was extracted with ethyl acetate and the ethyl acetate solution was washed with brine, dried over $\mathrm{Na}_{2} \mathrm{SO}_{4}$, and concentrated. Chromatography of the residue on silica gel using 3\% isopropyl alcohol in ethyl acetate afforded crude $5(0.94 \mathrm{~g})$ which was contaminated with starting material 4. To a solution of the crude 5 in $25 \mathrm{ml}$ of ethanol was added $0.42 \mathrm{~g}$ of $\mathrm{NaOH}$ dissolved in $25 \mathrm{ml}$ of water. After stirring for 1 day at room temperature, the product was extracted with ethyl acetate and the ethyl acetate solution was washed with brine and dried over $\mathrm{Na}_{2} \mathrm{SO}_{4}$. The solvent was removed to give $0.26 \mathrm{~g}(11 \%)$ of 5 . NMR $\delta: 1.10(9 \mathrm{H}, \mathrm{s}), 4.85(2 \mathrm{H}, \mathrm{s}), 7.05(1 \mathrm{H}$, broad s), 7.0-7.5 $(5 \mathrm{H}, \mathrm{m}), 7.42(1 \mathrm{H}$, broad s).

\section{1-(3,3-Dimethyl-2-hydroxybutyl)-5-phenylimidazole (6)}

To a solution of $5(0.19 \mathrm{~g}, 0.79 \mathrm{mmol})$ in $5 \mathrm{ml}$ of ethanol was added sodium borohydride $(90 \%, 0.26 \mathrm{~g}, 6.2 \mathrm{mmol})$. After stirring for $14 \mathrm{hr}$ at room temperature, the mixture was concentrated and $25 \mathrm{ml}$ of water was added. The product was extracted with ethyl acetate, and the ethyl acetate layer was washed with brine and dried over $\mathrm{Na}_{2} \mathrm{SO}_{4}$. Concentration of the solvent followed by recrystallization of the residue from benzenehexane (1: 3) afforded $20 \mathrm{mg}(10 \%)$ of $6, \mathrm{mp} 127-133^{\circ} \mathrm{C}$. NMR $\delta: 0.87(9 \mathrm{H}, \mathrm{s}), 6.88(1 \mathrm{H}$, broad s), 6.9-7.8 $(5 \mathrm{H}, \mathrm{m}), 7.55(1 \mathrm{H}$, broad $\mathrm{s})$.

\section{G eneral method for the preparation of 1,5-disubstituted imidazoles} (Method A)

\section{1-Butyl-5-phenylimidazole (7)}

Butylamine $(0.27 \mathrm{ml}, 2.7 \mathrm{mmol})$ was added to a solution of 1-cyano-2-phenyl-1tosylethene (2, $\mathrm{R}^{5}=$ phenyl, $\left.0.40 \mathrm{~g}, 1.4 \mathrm{mmol}\right)$ in $5 \mathrm{ml}$ of methanol and stirred for $3 \mathrm{hr}$ at room temperature. After diluting with water, the product was extracted with dichloromethane and the dichloromethane solution was washed with brine, dried over $\mathrm{Na}_{2} \mathrm{SO}_{4}$, and concentrated. The residue was chromatographed on silica gel and eluted with $3 \%$ isopropyl alcohol in ethyl acetate. Concentration of the eluate gave $0.24 \mathrm{~g}(86 \%)$ of 7 . NMR $\delta: 0.81(3 \mathrm{H}, \mathrm{t}, J=7 \mathrm{~Hz}), 1.0-1.8(4 \mathrm{H}, \mathrm{m}), 3.93(2 \mathrm{H}, \mathrm{t}, J=7 \mathrm{~Hz}), 7.02(1 \mathrm{H}, \mathrm{d}, J=$ $1 \mathrm{~Hz}), 7.2-7.4(5 \mathrm{H}, \mathrm{m}), 7.50(1 \mathrm{H}, \mathrm{d}, J=1 \mathrm{~Hz})$.

Compounds $8-10,12$ and $\mathbf{2 4 - 2 8}$ were similarly prepared, starting from the corre- 
sponding amines and 1-isocyano-1-tosyl-1-alkenes (2).

1-Isobutyl-5-phenylimidazole (8). Yield 93\%. NMR $\delta: 0.67(6 \mathrm{H}, \mathrm{d}, \boldsymbol{J}=7 \mathrm{~Hz}), 1.48$ $1.94(1 \mathrm{H}, \mathrm{m}), 3.67(2 \mathrm{H}, \mathrm{d}, \boldsymbol{J}=7 \mathrm{~Hz}), 6.93(1 \mathrm{H}, \mathrm{d}, \boldsymbol{J}=1 \mathrm{~Hz}), 7.2-7.3(5 \mathrm{H}, \mathrm{m}), 7.38(1 \mathrm{H}, \mathrm{d}, \boldsymbol{J}=$ $1 \mathrm{~Hz})$.

1-Neopentyl-5-phenylimidazole (9). Yield 79\%. mp 104-106 $6^{\circ} \mathrm{C}$. NMR $\delta: 0.72(9 \mathrm{H}$, s), $3.83(2 \mathrm{H}, \mathrm{s}), 6.99(1 \mathrm{H}, \mathrm{s}), 7.2-7.5(5 \mathrm{H}, \mathrm{m}), 7.51(1 \mathrm{H}, \mathrm{s})$.

1-(3.3-Dimethylbutyl)-5-phenylimidazole (10). Yield $86 \%$. mp $58-61^{\circ} \mathrm{C} . \mathrm{NMR} \delta$ : $0.84(9 \mathrm{H}, \mathrm{s}), 1.4-1.6(2 \mathrm{H}, \mathrm{m}), 3.8-4.1(2 \mathrm{H}, \mathrm{m}), 7.01(1 \mathrm{H}$, broad s), 7.3-7.4 $(5 \mathrm{H}, \mathrm{m}), 7.51(1 \mathrm{H}$, broad s).

1-Phenethyl-5-phenylimidazole (12). Yield 78\%. NMR $\delta: 2.82(2 \mathrm{H}, \mathrm{t}, \boldsymbol{J}=8 \mathrm{~Hz})$, $4.16(2 \mathrm{H}, \mathrm{t}, J=8 \mathrm{~Hz}), 6.8-7.5(12 \mathrm{H}, \mathrm{m})$.

5-(2-Chlorophenyl)-1-neopentylmidazole (24). Yield 59\%. mp 79-81 ${ }^{\circ} \mathrm{C}$. NMR $\delta$ : $0.74(9 \mathrm{H}, \mathrm{s}), 3.82(2 \mathrm{H}, \mathrm{s}), 7.01(1 \mathrm{H}$, broad s), 7.1-7.4 $(4 \mathrm{H}, \mathrm{m}), 7.52(1 \mathrm{H}$, broad s).

5-(4-Chlorophenyl)-1-neopentylimidazole (25). Yield 60\%. mp 96-98 $\mathrm{C}$. NMR $\delta$ : $0.73(9 \mathrm{H}, \mathrm{s}), 3.80(2 \mathrm{H}, \mathrm{s}), 7.00(1 \mathrm{H}, \mathrm{s}), 7.1-7.5(4 \mathrm{H}, \mathrm{m}), 7.53(1 \mathrm{H}, \mathrm{s})$.

5-(3-Chlorophenyl)-1-neopentylimidazole (26). Yield 25\%. mp 63-68 ${ }^{\circ} \mathrm{C}$. NMR $\delta$ : $0.76(9 \mathrm{H}, \mathrm{s}), 3.65(2 \mathrm{H}, \mathrm{s}), 7.00(1 \mathrm{H}$, broad s $), 7.2-7.5(4 \mathrm{H}, \mathrm{m}), 7.55(1 \mathrm{H}$, broad s).

1-Butyl-5-(3-chlorophenyl)imidazole (27). Yield 29\%. NMR $\delta: 0.79(3 \mathrm{H}, \mathrm{t}, J=7$ $\mathrm{Hz}), 1.0-1.7(4 \mathrm{H}, \mathrm{m}), 3.79(2 \mathrm{H}, \mathrm{t}, J=7 \mathrm{~Hz}), 7.00(1 \mathrm{H}, \mathrm{d}, \mathrm{J}=1 \mathrm{~Hz}), 7.2-7.5(4 \mathrm{H}, \mathrm{m}), 7.56(1 \mathrm{H}$, $\mathrm{d}, J=1 \mathrm{~Hz})$.

5-(3-Chlorophenyl)-1-pentylimidazole (28). Yield 25\%. NMR $\delta: 0.80(3 \mathrm{H}, \mathrm{t}, J=6$ $\mathrm{Hz}), 0.8-1.7(6 \mathrm{H}, \mathrm{m}), 3.79(2 \mathrm{H}, \mathrm{t}, \boldsymbol{J}=7 \mathrm{~Hz}), 7.00(1 \mathrm{H}, \mathrm{d}, \boldsymbol{J}=1 \mathrm{~Hz}), 7.1-7.6(4 \mathrm{H}, \mathrm{m}), 7.55(1 \mathrm{H}$, $\mathrm{d}, J=1 \mathrm{~Hz})$.

(Method B)

5-(2-Hydroxyphenyl)-1-neopentylimidazole (15).

A mixture of salicylaldehyde $(0.65 \mathrm{~g}, 5.3 \mathrm{mmol})$,neopentylamine $(1.0 \mathrm{~g}, 11.5 \mathrm{mmol})$, and anhydrous $\mathrm{MgSO}_{4}\left(3.6 \mathrm{~g}, 30 \mathrm{mmol}\right.$ ) was refluxed for $2 \mathrm{hr} . \mathrm{MgSO}_{4}$ was filtered off, and the filtrate was concentrated under reduced pressure. The residue was dissolved in $20 \mathrm{ml}$ of methanol, and to the mixture was added $\mathrm{K}_{2} \mathrm{CO}_{3}(3.5 \mathrm{~g}, 25 \mathrm{mmol})$ and tosylmethylisocyanide $(1.2 \mathrm{~g}, 6.2 \mathrm{mmol})$. After refluxing for $2 \mathrm{hr}$, the solvent was evaporated and water $(50 \mathrm{ml})$ was added to the residue. The precipitate was collected by filtration and recrystallized from ethanol and water to afford $1 \mathrm{~g}(82 \%)$ of $15, \mathrm{mp} 247-$

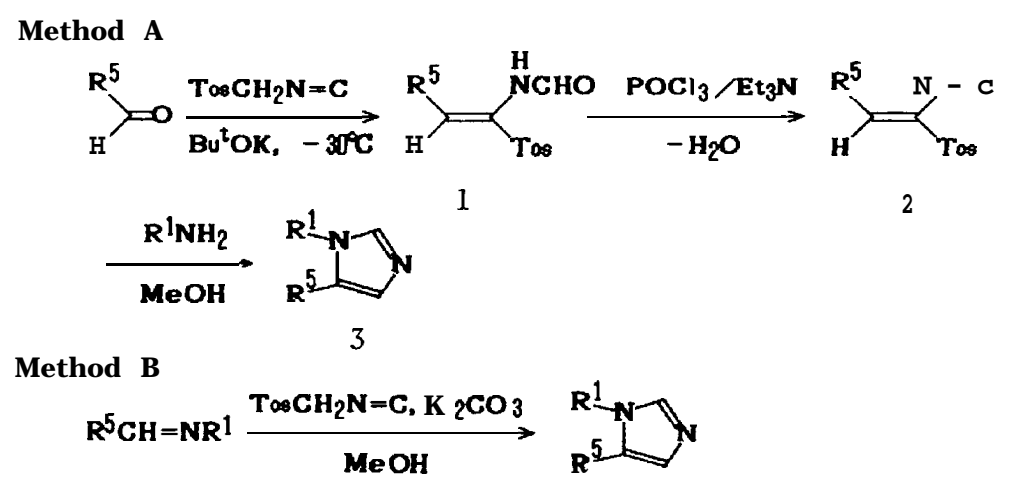

Scheme 1 Syntheses of 1,5-disubstituted imidazoles 
$248^{\circ} \mathrm{C}$. NMR $6: 0.72(9 \mathrm{H}, \mathrm{s}), 3.76(2 \mathrm{H}, \mathrm{s}), 6.7-7.6(7 \mathrm{H}, \mathrm{m})$.

Compounds 16-21 were similarly prepared, starting from the appropriate amines and salicylaldehyde.

5-(2-Hydroxyphenyl)-1-isobutylimidazole (16). Yield $78 \%$. mp $203-204^{\circ} \mathrm{C}$ (recrystallized from ethanol and water). NMR $\delta: 0.74(6 \mathrm{H}, \mathrm{d}, J=7 \mathrm{~Hz}), 1.5-2.0(1 \mathrm{H}, \mathrm{m}), 3.70$ $(2 \mathrm{H}, \mathrm{d}, \boldsymbol{J}=7 \mathrm{~Hz}), 6.7-7.6(7 \mathrm{H}, \mathrm{m})$.

1-Butyl-5-(2-hydroxyphenyl)imidazole (17). Yield 78\%. mp $171-173^{\circ} \mathrm{C}$ (recrystallized from ethanol and water). NMR $\delta: 0.80(3 \mathrm{H}, \mathrm{t}, J=7 \mathrm{~Hz}), 0.96-2.8(4 \mathrm{H}, \mathrm{m}), 3.86(2 \mathrm{H}$, $\mathrm{t}, \boldsymbol{J}=7 \mathrm{~Hz}), 6.7-7.6(7 \mathrm{H}, \mathrm{m})$.

5-(2-Hydroxyphenyl)-1-pentylimidazole (18). Yield 73\%. mp $163-164^{\circ} \mathrm{C}$ (recrystallized from ethanol and water). NMR $\delta: 0.80(3 \mathrm{H}, \mathrm{t}, J=7 \mathrm{~Hz}), 0.9-1.8(6 \mathrm{H}, \mathrm{m}), 3.88(2 \mathrm{H}$, t, $\boldsymbol{J}=7 \mathrm{~Hz}), 6.7-7.4(6 \mathrm{H}, \mathrm{m}), 7.48(1 \mathrm{H}, \mathrm{d}, \boldsymbol{J}=1 \mathrm{~Hz})$.

1-(3,3-Dimethylbutyl)-5-(2-hydroxyphenyl)imidazole (19). Yield 61\%. mp 198$200^{\circ} \mathrm{C}$ (recrystallized from ethanol and water). NMR $\delta: 0.79(9 \mathrm{H}, \mathrm{s}),, 1.3-1.6(2 \mathrm{H}, \mathrm{m})$, 3.7-4.0 (2H, m), 6.8-7.6 (6H, m), 7.5 (1H, d, $J=1 \mathrm{~Hz})$.

1-Benzyl-5-(2-hydroxyphenyl)imidazole (20). Yield $56 \%$. mp $194-195^{\circ} \mathrm{C}$ (recrystallized from acetone). NMR $\delta: 5.4(2 \mathrm{H}, \mathrm{s}), 6.7-7.6(12 \mathrm{H}, \mathrm{m})$.

5-(2-Hydroxyphenyl)-1-phenethylimidazole (21). Yield $72 \%$. mp $199-201^{\circ} \mathrm{C}$ (recrystallized from ethanol ). NMR $\delta: 2.80(2 \mathrm{H}, \mathrm{t}, \boldsymbol{J}=7 \mathrm{~Hz}), 4.14(2 \mathrm{H}, \mathrm{t}, \mathrm{J}=7 \mathrm{~Hz}), \quad 6.7-7.6$ $(12 \mathrm{H}, \mathrm{m})$.

\section{5-(2-Methoxyphenyl)-1-neopentylimidazole (22).}

To a suspension of sodium hydride $(60 \%, 0.1 \mathrm{~g}, 2.4 \mathrm{mmol})$ in $10 \mathrm{ml}$ of dimethylformamide was added compound $15(0.46 \mathrm{~g}, 2 \mathrm{mmol})$, and the mixture was stirred for $1 \mathrm{hr}$ at room temperature. To the mixture was added methyl iodide $(0.3 \mathrm{~g}, 2.1 \mathrm{mmol})$. After stirring for $15 \mathrm{hr}$ at room temperature, to the mixture was added $50 \mathrm{ml}$ of water, and the product was extracted with ether. The ether was washed with brine and dried over $\mathrm{Na}_{2} \mathrm{SO}_{4}$. After removal of the solvent, the residue was chromatographed on silica gel by elution with hexane-ethyl acetate (1: 1). Concentration of the eluate under reduced pressure followed by recrystallization of the residue from hexane afforded $0.1 \mathrm{~g}(21 \%)$ of $22, \mathrm{mp} 96-98^{\circ} \mathrm{C}$. NMR $\delta: 0.72(9 \mathrm{H}, \mathrm{s}), 3.64(2 \mathrm{H}, \mathrm{s}), 3.86(3 \mathrm{H}, \mathrm{s}), 6.8-7.6(6 \mathrm{H}, \mathrm{m})$.

5-(2-Ethoxyphenyl)-1-neopentylimidazole (23) was prepared in the same manner, using ethyl bromide. Yield $66 \% . \mathrm{mp} 76-78^{\circ} \mathrm{C}$ (recrystallized from hexane). NMR $\delta$ : $0.72(9 \mathrm{H}, \mathrm{s}), 1.30(3 \mathrm{H}, \mathrm{t}, J=7 \mathrm{~Hz}), 3.68(2 \mathrm{H}, \mathrm{s}), 4.00(2 \mathrm{H}, \mathrm{q}, J=7 \mathrm{~Hz}), 6.8-7.6(6 \mathrm{H}, \mathrm{m})$.

Compounds 11, 13, 14, 29 and 1-decylimidazole were prepared according to the procedure reported previously (Kuwano et al., 1985).

\section{Lettuce seedling test}

Onto a sheet of filter paper placed on the bottom of a Petri dish of $9 \mathrm{~cm}$ in diameter was poured $1 \mathrm{ml}$ of acetone solution of the test compounds. After evaporation of the solvent, $5 \mathrm{ml}$ of deionized water was poured into the dish, and 20 seeds of the lettuce (Lactuca sativa L. c.v. Sacramento) were placed in it. Plants were maintained under the following environmental conditions : temperature, $25 \pm 1{ }^{\circ} \mathrm{C}$; relative humidity, $60 \pm$ $5 \% ; 12 \mathrm{hr}$ photoperiod; photosynthetically available radiation, $80 \mu \mathrm{mol} \cdot \mathrm{m}^{-2} \cdot \mathrm{s}^{-1}$ (white fluorescent light, $40 \mathrm{~W} \times 2$ ).

The growth regulatory activity of compounds was evaluated after 4 days by inspecting the rate of growth inhibition or stimulation of the hypocotyls and radicles. The rates were determined by percentages of the averaged lengths of hypocotyls or 
radicles of treated plants to those of controls and indicated according to the following scale :

Inhibition :

$-5 \geqq 80 \%>-4 \geqq 70 \%>-3 \geqq 50 \%>-2 \geqq 30 \%>-1 \geqq 10 \%>0$

Stimulation :

$5 \geqq 80 \%>4 \geqq 70 \%>3 \geqq 50 \%>2 \geqq 30 \%>1 \geqq 10 \%>0$

\section{RESULTS AND DISCUSSIONS}

\section{Synthesis}

1, 5-Disubstituted imidazoles were prepared by two different procedures using tosylmethylisocyanide (TosMIC) according to methods described by van Leusen (1977, 1979) (Scheme 1) : (Method A) the reaction of amines with 1 -isocyano- 1- tosyl- 1alkenes (2), which are the dehydration products of the $\mathrm{N}$-(1-tosyl-1-alkenyl)formamides (1) obtained by the reaction of TosMIC with the corresponding aldehydes ; (Method B) the reaction of the corresponding aldimines with TosMIC. Only for the synthesis of 1-substituted-5-(2-hydroxyphenyl) imidazoles (compounds 15-21) Method B was used, because of the stability of the imines derived from amines and salicylaldehyde. In this case the products were obtained in high yield. Compound 5 was prepared by alkylation of compound 4 with t-butyllithium. The reduction of 5 with sodium borohydride afforded compound 6 .

Biological activities

Table 1 shows the effects of a series of 1-substituted-5-phenylimidazoles on the growth of lettuce seedlings. Most of the compounds inhibited the growth of hypocotyls and had weak stimulating activity to the growth of roots at $10 \mathrm{ppm}$. The butyl (7), neopentyl (9), benzyl (11), and phenethyl(12) analogs exhibited high inhibitory activity, while the compounds which have a long alkyl chain such as citronellyl(13) and dodecyl (14) at 1-position had no activity. The activity of the isobutyl (8) and 3, 3-dimethylbutyl (10) analogs was somewhat lower compared with that of compound 7 or 9. 1Decylimidazole which is reported to inhibit the gibberellin biosynthesis (Wada, 1978) showed weak activity in this bioassay. Compound 6 having a structural resemblance to paclobutrazol which is developed as a plant growth regulator showed comparatively low activity.

In Table 2 there are presented bioassay data for a variety of 1, 5-disubstituted imidazoles. In a series of 5-aryl-1-neopentylimidazoles, the introduction of a 2hydroxy (15), 2-methoxy (22), 2-ethoxy (23), or 3-chloro (25) substituent on the benzene ring increased the inhibitory activity in the growth of hypocotyls. No inhibition of the root growth was found at the concentrations causing a strong growth inhibition of the hypocotyls. In contrast to the result found in compound 15, it has been found that for the benzyl (11) and phenethyl (12) analogs the introduction of a 2-hydroxy group (compounds 20 and 21) slightly decreased the activity. In the butyl analogs, the presence of a 2-hydroxy (17) or 3-chloro (27) substituent on the benzene ring did not affect the activity. Replacement of the phenyl group (9) by a styryl group (29) decreased the activity. None of the compounds in Tables 1 and 2 showed inhibitory activity at $1 \mathrm{ppm}$, while paclbutrazol inhibited the hypocotyl growth of the lettuce even at $0.1 \mathrm{ppm}$. 
Table 1. Growth regulatory activity of 1-substituted-5-phenyl. imidazoles.

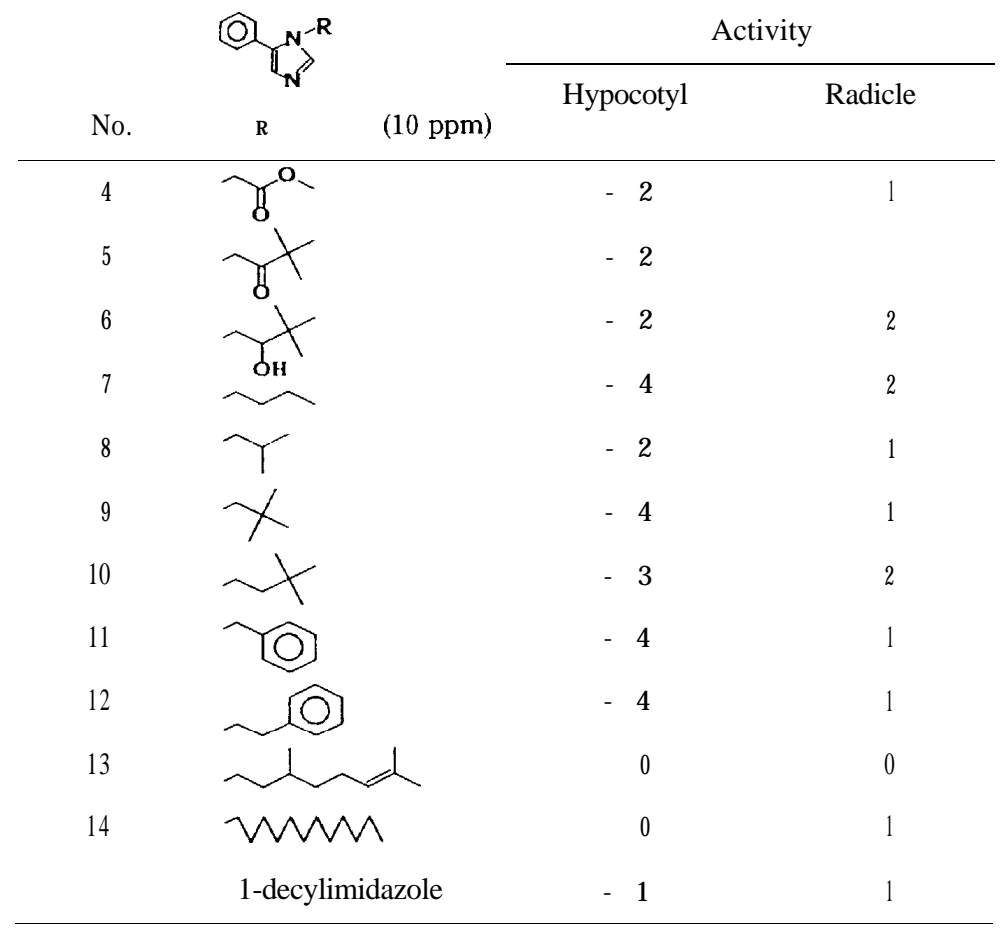

Table 3 shows the I,, values of several representative compounds for the lettuce hypocotyl growth. There was little difference in activity among those compounds except for compound 24. The growth-retardant activity of these 1,5-disubstituted imidazoles was annulled fully by application of gibberellic acid (GA,) (Table 4), suggesting that the growth-retardant activity is due to interference in gibberellin biosynthesis.

On the basis of the preliminary biological data described in this article, it is concluded that 1,5-disubstituted imidazoles represent reasonable leads for the development of new plant growth regulators. Further studies on this series of compounds are in progress.

\section{REFERENCES}

Köller, W. 1987 Isomers of sterol synthesis inhibitors : Fungicidal effects and plant growth regulator activities. Pestic. Sci., 18: 129-147

Kuwano, E., R. Takeya and M. Eto 1985 Synthesis and antijuvenile hormone activity of 1-substituted 5-((E)-2,6-dimethyl-1,5-heptadienyl )imidazoles. Agric. Biol. Chem., 49 : 483-486

Rademacher, W., H. Fritsch, J. E. Graebe, H. Sauter and J. Jung 1987 Tetcyclacis and triazole-type plant growth retardants : Their influence on the biosynthesis of gibberellins and other metabolic processes. Pestic. Sci., $21:$ 241-252

Sisler, H. D., N. N. Ragsdale and W. F. Waterfield 1984 Biochemical aspects of the fungitoxic and 
Table 2. Growth regulatory activity of 1, 5-disubstitued imidazoles.

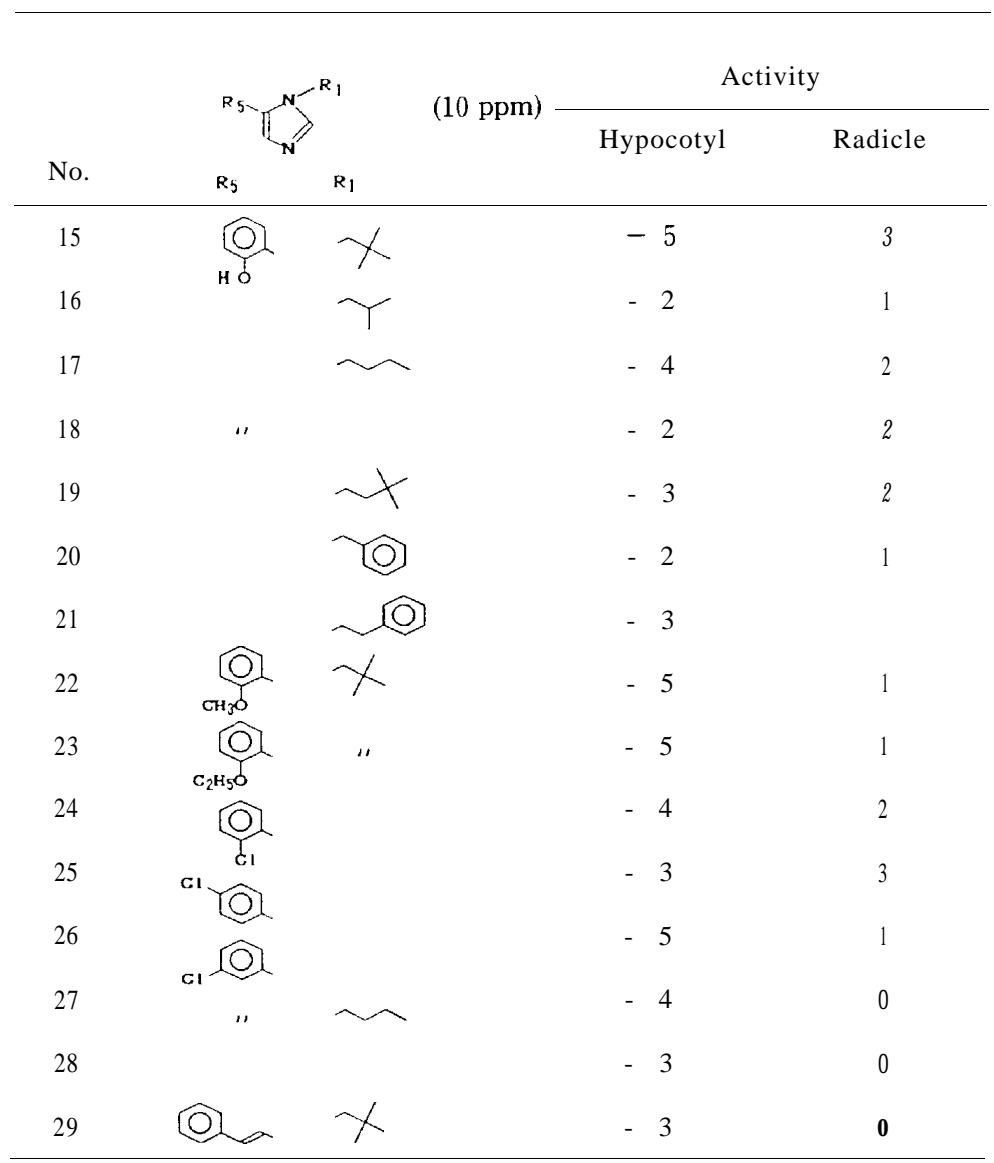

Table 3. Inhibition of lettuce hypocotyl growth by 1, 5-disubstituted imidazoles.

\begin{tabular}{cc}
\hline Compound & $\mathrm{I}_{50}(\mu \mathrm{M})$ \\
\hline 7 & 18 \\
9 & 18 \\
12 & 17 \\
22 & 17 \\
24 & 35 \\
26 & 18 \\
\hline
\end{tabular}


Table 4. Effect of exogeneous gibberellic acid (GA,) on the growth retardation of lettuce seedlings by 1,5-disubstituted imidazoles.

\begin{tabular}{ccc}
\hline \multirow{2}{*}{ Compound } & Relative length of hypocotyl \\
\cline { 2 - 3 }$(10 \mathrm{ppm})$ & GA, concentration (ppm) \\
& 0 & 0.1 \\
Control & & \\
9 & 1.0 & 3.4 \\
22 & 0.4 & 1.7 \\
24 & 0.1 & 1.4 \\
26 & 0.4 & 2.0 \\
& 0.2 & 1.2 \\
\hline
\end{tabular}

growth regulatory action of fenarimol and other pyridin-5-ylmethanols. Pestic. Sci., 15 167-176

Van Leusen, A. M., J. Wildeman and 0. H. Oldenziel 1977 Base-induced cycloaddition of sulfonylmethyl isocyanides to $\mathrm{C}, \mathrm{N}$ double bonds. Synthesis of 1, 5-disubstituted and 1, 4, 5-trisubstituted imidazoles from aldimines and imidoyl chlorides. J. Org. Chem., 42: 1153-1159

Van Leusen, A. M., F. J. Schaart and D. Van Leusen 1979 Synthesis of 1-isocyano-1-tosyl-1alkenes and their use in the preparation of imidazoles. Recl.Trav. Chim. Pays- $\&$ s, $98:$ 258-262

Wada, K., 1978 New gibberellin biosynthesis inhibitors, 1- $n$-decyl- and 1-geranylimidazole : inhibitors of (-)-kaurene 19-oxidation. Agric.Biol.Chem., 42 : 2411-2413 